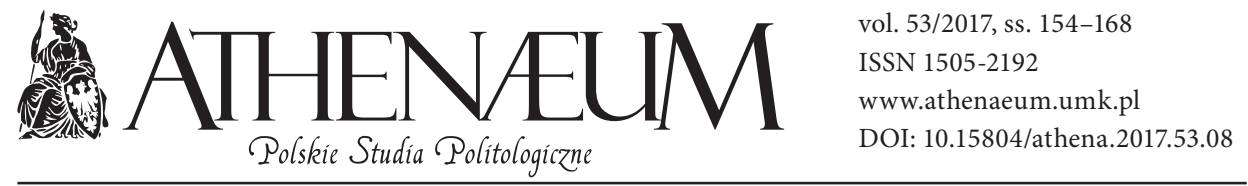

\title{
SERWISY SPOŁECZNOŚCIOWE JAKO NARZĘDZIE KOMUNIKOWANIA WYBORCZEGO. KANDYDACI W WYBORACH PARLAMENTARNYCH W ROKU 2015 NA FACEBOOKU
}

\author{
SOCIAL MEDIA AS THE INSTRUMENT OF ELECTORAL \\ COMMUNICATION. CANDIDATES IN THE 2015 \\ PARLIAMENTARY ELECTIONS ON FACEBOOK
}

Leszek Porębski*, Marzena Żurek**

\begin{abstract}
ABSTRAKT
Artykuł jest analizą sposobu wykorzystania serwisu społecznościowego Facebook przez kandydatów w polskich wyborach parlamentarnych w roku 2015. Wyniki badań dowodzą, że tylko niespełna jedna trzecia kandydatów była w czasie kampanii wyborczej aktywna na Facebooku. Co więcej, materiały informacyjne były znacznie częściej publikowane niż treści o charakterze mobilizacyjnym czy promocyjnym. Nie wykazano też statystycznej zależności między płcią, wiekiem i miejscem zamieszkania kandydatów a intensywnością korzystania z Facebooka w czasie kampanii wyborczej.
\end{abstract}

Słowa kluczowe: komunikowanie polityczne, kampanie wyborcze, nowe technologie informacyjne i komunikacyjne, serwisy społecznościowe, Facebook

* AGH w Krakowie, Wydział Humanistyczny.

** AGH w Krakowie, Wydział Humanistyczny.
The paper is an analysis of the mode in which candidates in Polish parliamentary elections in 2015 made use of Facebook. The research results prove that no more than one third of candidates was active on Facebook during the campaign. Moreover, information were much more often published than promoting or mobilizing content. No statistical correlation was found between the intensity of Facebook use and sex, age, or place of residence of candidates either.

Keywords: political communication, electoral campaigns, ICT, social media, Facebook 


\section{WPROWADZENIE}

Przemiany społeczne związane $\mathrm{z}$ rozwojem technologii informacyjnych i komunikacyjnych (Information and Communication Technologies - ICT) są widoczne w wielu sferach życia codziennego niedługo po pojawieniu się nowych urządzeń, aplikacji czy rozwiązań technicznych. Dotyczy to w równym stopniu sposobu robienia zakupów, kształtu kontaktów interpersonalnych, co mechanizmów uczestnictwa w życiu politycznym. Już w roku 2006, a więc dwa lat po pojawieniu się w Stanach Zjednoczonych Facebooka (FB), prawie jedna trzecia kandydatów do amerykańskiego Senatu $(31,5 \%)$ i co ósmy ubiegający się o mandat w wyborach do Izby Reprezentantów (12,8\%) byli obecni na tym serwisie społecznościowym (Williams, Gulati, 2007, s. 8).

To właśnie rozwój mediów społecznościowych, których FB jest najbardziej rozpoznawalnym reprezentantem, wyznacza rytm przemian cyberprzestrzeni w ostatniej dekadzie. Proces ten, wiązany zazwyczaj z pojęciem Sieci 2.0 (Web 2.0), oznacza gwałtowny rozwój interaktywnego potencjału Internetu i udostępnienie narzędzi umożliwiających każdemu internaucie publikowanie stworzonych przez siebie treści. Ma to oczywiście istotne konsekwencje także w sferze polityki. „Aplikacje typu Sieć 2.0 mają podstawowe znaczenie dla dyskursu demokratycznego, ponieważ ułatwiają komunikowanie między kandydatami i wyborcami, poszerzają sferę publiczną, oferują platformę dla mniej znanych kandydatów i starają się zapewnić wyborcom równy dostęp do informacji politycznej" (Towner, 2012, s. 195).

Niezależnie od tego, na ile przytoczone możliwości są rzeczywiście realizowane, serwisy społecznościowe - podobnie jak bardziej tradycyjne narzędzia sieciowe - stały się trwałym elementem politycznego instrumentarium, wykorzystywanego zarówno przez obywateli, jak i polityków. Procesy wyborcze, będące kluczowym aspektem demokracji, mają w tym kontekście szczególne znaczenie. To właśnie w czasie kampanii wyborczych skuteczność komunikacji z obywatelami staje się podstawowym czynnikiem warunkującym sukces ubiegających się o mandat polityków. Z tego punktu widzenia media społecznościowe wydają się narzędziem stwarzającym wyjątkowo obiecujące możliwości. „Natychmiastowość oddziaływania mediów społecznościowych, w połączeniu z wielką liczbą zaangażowanych ludzi oznaczają, że rola dobrze prowadzonej obecności w mediach społecznościowych jest bezcenna. Media społecznościowe otwierają świat, w którym zwolennicy sami angażują się po twojej stronie - jest to coś znacznie bardziej skutecznego, autentycznego i osobistego niż tradycyjne 
reklamy stosowane w kampanii" (Shaw, 2013, s. 81-82). W konsekwencji, dla polityka startującego współcześnie w wyborach: „pewne rzeczy są obowiązkowe: Facebook, Twitter, YouTube i strona internetowa. Stanowią one absolutne minimum w prowadzeniu kampanii cyfrowej [...]” (s. 82).

Przytoczone słowa pisane były z perspektywy amerykańskiej. Warto jednak zastanowić się, w jakim stopniu są one adekwatnym opisem kampanii wyborczych prowadzonych przez polskich polityków. Na ile serwisy społecznościowe stały się w polskich realiach wyborczych standardowym narzędziem wykorzystywanym w kampanii? Jakie treści dominują w komunikowaniu wyborczym realizowanym przez serwisy społecznościowe? Próba odpowiedzi na tak sformułowane pytania - w odniesieniu do serwisu Facebook - jest podstawowym celem tego tekstu.

\section{FACEBOOK W KAMPANIACH WYBORCZYCH JAKO PRZEDMIOT BADAŃ}

Analizy poświęcone wykorzystaniu Facebooka w prowadzeniu kampanii wyborczych zaczęły pojawiać się kilka lat po tym, gdy pierwsi politycy uznali media społecznościowe za obiecujące narzędzie dla pozyskiwania wyborców. Szczególnie intensywnie kwestia ta badana była oczywiście w Stanach Zjednoczonych (zob. np. Vaccari, Nielsen, 2013; Williams, Gulati, 2013), zwłaszcza po zwycięskich i uznanych za modelowe - z punktu widzenia wykorzystania mediów społecznościowych - kampaniach prezydenckich Barracka Obamy (zob. np. Hendricks, Denton, 2010; Robertson, Vatrapu, Median, 2010; Bimber, 2014; Gerodimos, Justinussen, 2015). Wraz z gwałtowną ekspansją serwisów społecznościowych wzrosła też liczba badań poświęconych ich obecności w kampaniach wyborczych. Przedmiotem analizy stało się więc zarówno syntetyczne podsumowanie sposobu wykorzystywania FB w wyborach w konkretnych krajach (Williamson, 2010; Karlsen, 2011; Hansen, Kosiara-Pedersen, 2014)ํㅜ, jak i bardziej szczegółowe kwestie. Do tych ostatnich należą choćby relacja między kampanijną aktywnością online i offline (Štetka, Mazák, 2014), determinanty wyboru konkretnych typów

${ }^{1}$ Do tej pory ukazało się niewiele tekstów analizujących wykorzystanie mediów społecznościowych w perspektywie porównawczej. Do wyjątków należy opracowanie Townera (2012), będące podsumowaniem roli odgrywanej przez narzędzia Web $2.0 \mathrm{w}$ kampaniach wyborczych w Stanach Zjednoczonych, Wielkiej Brytanii, Niemczech, Francji, Izraelu i Australii. 
narzędzi sieciowych i serwisów społecznościowych (Dolezal, 2015) czy potencjał Facebooka jako platformy debaty wyborczej (Camaj, Santana, 2015).

Wykorzystanie mediów społecznościowych, w tym FB, stało się także przedmiotem zainteresowania polskich badaczy. Dotyczy to zarówno okresu niezwiązanego z wyborami - na szczeblu samorządowym (Piechota, 2012; Choroś, Skrabacz, 2014) i w odniesieniu do partii politycznych (Porębski, Karasek-Kędzior, 2014; Bodys, 2015; Porębski, Karasek-Kędzior, 2015), jak i prowadzenia kampanii wyborczych. W tym ostatnim kontekście pojawiły się analizy dotyczące lokalnej sceny politycznej (Stopczyński, 2015), wyborów prezydenckich (Olczyk, 2015), ale również wyborów parlamentarnych (Fras, 2012; Kowalik, 2013). W sumie, w kontekście polskim można mówić dopiero o początkowej fazie badań, raczej „punktowo” eksplorujących konkretne kwestie niż dostarczających całościowej charakterystyki analizowanych problemów.

Wszystko to sprawia, że mimo ciągle prowadzonych badań nie dysponujemy jeszcze szczegółowym opisem stopnia wykorzystania serwisów społecznościowych w kampaniach wyborczych, a tym bardziej spójnym obrazem roli odgrywanej przez narzędzia typu Web 2.0 w kształtowaniu zachowań wyborców i determinowaniu sukcesu wyborczego. Nawet w odniesieniu do demokracji lokalnej, zupełnie różna jest przecież logika wykorzystania Facebooka w wyborach wójta małej gminy w porównaniu z wyłanianiem prezydenta wielomilionowej metropolii. Także w kontekście samych wyborów parlamentarnych liczba zmiennych determinujących sposób wykorzystania mediów społecznościowych jest tak duża ${ }^{2}$ że ciągle znacznie więcej pytań czeka na udzielenie odpowiedzi, niż może być uznanych za poddane konkluzywnej analizie. Wydaje się więc, że problem stopnia i sposobu wykorzystania ICT (w tym narzędzi Sieci 2.0, a zwłaszcza serwisów społecznościowych) w procesach wyborczych pozostaje jednym z istotniejszych i najciekawszych poznawczo wyzwań badawczych współczesnej politologii.

${ }^{2}$ Wymienić można choćby stopień rozpowszechnienia ICT wśród wyborców, demograficzną i społeczną charakterystykę kandydatów, większościowy lub proporcjonalny system wyboczy czy poziom aktywności obywatelskiej w społeczeństwie. 


\section{CEL, ZAKRES I METODA BADAŃ}

Jak wspomniano wcześniej głównym celem tego tekstu jest ocena, na ile Facebook stał się serwisem powszechnie wykorzystywanym przez polskich polityków w kampaniach wyborczych oraz jakie jego funkcje odgrywają najistotniejszą rolę w kampanii realizowanej w Internecie. Tak sformułowane cele mają jednak charakter bardzo ogólny, dlatego przystępując do opracowania omawianego w dalszej części tekstu programu badań, sprecyzowanych zostało kilka szczegółowych pytań badawczych. Najistotniejsze z nich to: Jaka część kandydatów w wyborach posiada wyborcze strony na Facebooku? Jaka jest charakterystyka demograficzna i społeczna polityków obecnych na FB w związku z wyborami? Czy istnieje związek statystyczny pomiędzy konkretnymi zmiennymi a skłonnością do korzystania z FB w kampanii wyborczej? Z jaką intensywnością prowadzone są strony? Jaka tematyka dominuje wśród materiałów publikowanych na FB? Na ile w aktywności na Facebooku widoczne są różnice pomiędzy kandydatami różnych partii politycznych?

Analizie poddano kampanię wyborczą przed wyborami parlamentarnymi, odbywającymi się jesienią 2015 roku. W celu uzyskania precyzyjnej odpowiedzi na przytoczone pytania badawcze autorzy zdecydowali się na ograniczenie zakresu analizy do jednego okręgu wyborczego. Badania objęły wszystkich kandydatów ubiegających się o mandat poselski w okręgu nr 13, w skład którego wchodzi miasto (powiat grodzki) Kraków, powiat krakowski oraz powiaty miechowski i olkuski. Objęcie analizą całego okręgu wyborczego dało możliwość stworzenia w pełni reprezentatywnego obrazu analizowanych problemów na szczeblu ponadlokalnym. Warto też zwrócić uwagę, że tego typu podejście nie było dotychczas wykorzystywane w przypadku badań dotyczących wykorzystania FB w polskich kampaniach wyborczych ${ }^{3}$.

Ponieważ podstawowym przedmiotem prezentowanego projektu badawczego jest rola serwisu społecznościowego jako narzędzia komunikowania wyborczego, analizie poddano wyłącznie oficjalne strony (fanpage'e) na FB firmowane przez kandydatów z okręgu nr 13, a nie ich prywatne konta. Te ostatnie służą zazwyczaj

\footnotetext{
3 Spośród wymienionych wcześniej polskich opracowań tylko tekst Krzysztofa Kowalika, dotyczący wyborów parlamentarnych z roku 2011, miał zbliżony charakter. Obejmował on jednak profile prywatne, a nie oficjalne wyborcze strony (fanpage’e) kandydatów do parlamentu (a więc zarówno do Sejmu, jak i do Senatu). Inny był też okres prowadzenia badań oraz - co najistotniejsze - ich metodologia (por. Kowalik, 2013, s. 67-70).
} 
do kontaktów w zamkniętym kręgu znajomych i nie mają charakteru otwartego. Trudno więc traktować je jako narzędzia komunikowania w kontekście wyborczym. Badanie obejmowało całą kampanię wyborczą, tzn. okres od 16 września (dzień po opublikowaniu zarejestrowanych formalnie list kandydatów) do 23 października 2015 roku (24 października zaczynała się cisza wyborcza). Wszystkie materiały opublikowane w tym czasie na stronach kandydatów zostały zarchiwizowane, a następnie poddane szczegółowej analizie, w okresie od września 2015 do marca 2016 roku.

W badaniu zastosowano metodę ilościowej analizy zawartości. Po przeprowadzeniu fazy pilotażowej, opartej na obserwacji kont polityków startujących w wyborach prezydenckich (w maju 2015 roku), został skonstruowany klucz kategoryzacyjny, dzięki któremu przeanalizowano tematykę materiałów publikowanych na stronach prowadzonych przez kandydatów na FB. Każdy wpis został przypisany do jednej z pięciu kategorii szczegółowych: materiały promocyjne, mobilizacyjne, informacyjne, społeczno-gospodarcze oraz pozostałe, niemieszczące się we wcześniej wymienionych kategoriach („,inne”). Za wpisy promocyjne uznano wszystkie materiały budujące wizerunek kandydata jako osoby godnej poparcia (rekomendacje ze strony różnych osób, odniesienia do materiałów medialnych w udziałem kandydata itp.). Charakter mobilizacyjny miały prośby o wsparcie, materiały zachęcające użytkowników do udziału w wyborach, ale także np. do oddania głosu w sondach i prawyborach internetowych. Do kategorii wpisów informacyjnych zaliczono wszelkie materiały prezentujące biografię kandydata, informacje o spotkaniach $\mathrm{z}$ wyborcami, udziale w debatach przedwyborczych, a także techniczne informacje dotyczące przebiegu wyborów, spisu wyborców itd. Z kolei wpisy społeczno-gospodarcze to wszelkie formy aktywności niezwiązane bezpośrednio z udziałem w kampanii wyborczej, a odnoszące się do problemów podnoszonych $w$ debacie publicznej. W tej kategorii mieścily się więc m.in. wypowiedzi na temat życia gospodarczego, środowiska i ekologii, problemu uchodźców i szeroko rozumianej doraźnej polityki.

W badaniach uwzględniono także poziom aktywności kandydatów (liczbę wpisów na FB), a dla uzyskania pełniejszego obrazu opisywanych zjawisk dokonano statystycznej analizy związku tej zmiennej z podstawowymi zmiennymi demograficzno-społecznymi (płeć, wiek, miejsce zamieszkania).

Dzięki wstępnej analizie danych zebranych $w$ ramach realizacji projektu badawczego oraz dostępnych w literaturze wyników wcześniej przeprowadzonych badań sformułowano dwie hipotezy badawcze: 1) istnieje statystyczna korelacja wieku kandydatów i skłonności do korzystania Facebooka w kampanii 
wyborczej - kandydaci młodsi częściej posiadają stronę w serwisie społecznościowym i zamieszczają na niej więcej wpisów, 2) możliwość mobilizacji wyborców poprzez serwis społecznościowy jest w niewielkim stopniu wykorzystywana przez kandydatów, a w wykorzystaniu Facebooka wyraźnie dominuje funkcja informacyjna.

\section{KOMUNIKOWANIE WYBORCZE NA FACEBOOKU W POLSKICH WYBORACH PARLAMENTARNYCH W ROKU 2015}

\section{Poziom aktywności}

W wyborach do Sejmu jesienią 2015 roku w okręgu nr 13 zarejestrowanych zostało dziesięć list wyborczych, na których znajdowało się 251 kandydatek i kandydatów. Pięć partii politycznych umieściło na swych listach maksymalnie dopuszczalną liczbę kandydatów - 28 (PiS, PO, KORWiN, PSL, Kongres Nowej Prawicy). Najmniej liczna była z kolei lista Partii Razem, na której znalazło się tylko 18 osób. Wśród kandydatów 59\% stanowili mężczyźni, a 41\% kobiety. Dla prawie dwóch trzecich kandydatów (64\%) miejscem zamieszkania był Kraków, co piąty (19\%) kandydat to mieszkaniec wsi, a 17\% stanowily osoby mieszkające w innych miastach.

Spośród wszystkich zarejestrowanych kandydatów 78 osób, a więc niespełna co trzecia (31\%), posiadało swój fanpage na $\mathrm{FB}^{4}$. Prawie cała ta grupa (75 osób - 96\%) to jednocześnie posiadacze kont prywatnych. Co ciekawe, większość spośród 173 kandydatów, niemających swej oficjalnej strony (96 osób - 55\%) posiadało na Facebooku swoje profile prywatne. Dane te tworzą interesujący i dość spójny obraz. Populacja kandydatów w okręgu nr 13 dzieli się na trzy zbliżone wielkością grupy. Prawie równie liczni są kandydaci posiadający po dwa konta (prywatne i fanpage) i ci, którzy w ogóle nie są obecni na FB. Ci pierwsi mogą być uznani za osoby najbardziej aktywne w nowych mediach i rozumiejące ich potencjał w sferze polityki. Ci drudzy to ludzie pozostający całkowicie poza oddziaływaniem serwisów społecznościowych i zapewne zachowujący też dużą

\footnotetext{
${ }^{4} 60$ stron funkcjonowało od początku kampanii, w jej trakcie uruchomionych zostało kolejnych 18 fanpage'y.
} 
rezerwę do ICT w ogóle (choć weryfikacja tej tezy wymagałaby oczywiście dalszej eksploracji). Każda z wymienionych zbiorowości liczy ok. 30\% spośród wszystkich kandydatów, natomiast pozostałe prawie $40 \%$ to grupa osób co prawda obecnych w serwisach społecznościowych (wszyscy posiadają prywatny profil na FB), ale jednocześnie nie widzących potrzeby rozszerzenia tego typu doświadczeń na swą aktywność w kampanii wyborczej. Liczebność tej właśnie grupy może zaskakiwać, bo dowodzi, jak dużo aktywnych w życiu publicznym użytkowników sieci korzysta z dostępnych narzędzi w sposób wybiórczy, nie dostrzegając potencjału tkwiącego w ICT.

Różnice w częstości posiadania oficjalnej strony na FB pomiędzy kandydatami poszczególnych komitetów wyborczych są wyraźne, ale trudno wskazać $\mathrm{z}$ tego punktu widzenia wyraźne prawidłowości (zob. tabela 1). Jeśli brać pod uwagę odsetek osób startujących z konkretnej listy, które obecne są na Facebooku w formie fanpage'a, to liderami są Kukiz'15 (71\%) i PiS (61\%), a więc z jednej strony powstała niedługo przed wyborami organizacja obywatelska, z drugiej silna i dysponująca znaczącymi zasobami organizacyjnymi partia polityczna. Z kolei wśród komitetów, których przedstawiciele są najrzadziej obecni na FB, znaleźć można zarówno efemeryczne ugrupowanie „Szczęść Boże!” (5\%), najstarszą polską partię polityczną - PSL (7\%), ale także radykalnie prawicowy Kongres Nowej Prawicy (11\%) i radykalnie lewicową Partię Razem (11\%). Trudno więc jednoznacznie łączyć obecność wyborczą na FB z systemowością lub antysytemowością, okresem obecności konkretnego ugrupowania na scenie politycznej czy jego profilem ideowym. Wydaje się, że na poziomie okręgu wyborczego, a więc w odniesieniu do stosunkowo małej populacji osób ubiegających się o mandat poselski, najistotniejszym czynnikiem determinującym korzystanie z FB są wcześniejsze doświadczenia poszczególnych kandydatów, ich otwartość na ICT, a także indywidualne - często spontaniczne $e^{5}$ decyzje dotyczące sposobu prowadzenia kampanii.

${ }^{5}$ Ostatnie $\mathrm{z}$ analizowanych kont zostało utworzone 14 października, a więc na dziesięć dni przed końcem kampanii. Trudno w tym przypadku mówić o przemyślanej strategii kandydata. 
Tabela 1. Kandydaci posiadający oficjalne konto na Facebooku z podziałem na komitety wyborcze

\begin{tabular}{|c|c|c|}
\hline Nazwa komitetu & $\begin{array}{c}\text { Liczba kandydatów } \\
\text { posiadających konto }\end{array}$ & $\begin{array}{c}\text { \% kandydatów } \\
\text { na liście }\end{array}$ \\
\hline Prawo i Sprawiedliwość & 17 & 61 \\
Platforma Obywatelska & 11 & 39 \\
Partia Razem & 2 & 11 \\
KORWiN & 11 & 39 \\
Polskie Stronnictwo Ludowe & 2 & 7 \\
Zjednoczona Lewica & 5 & 19 \\
Kukiz'15 & 15 & 71 \\
Nowoczesna & 11 & 46 \\
„Szczęść Boże!”* & 1 & 5 \\
Kongres Nowej Prawicy & 3 & 11 \\
\hline
\end{tabular}

* Komitet Wyborczy Wyborców Grzegorza Brauna „Szczęść Boże!”.

Źródło: Opracowanie własne.

Wśród kandydatów posiadających strony na Facebooku znalazły się 32 kobiety, co stanowi $41 \%$ wszystkich osób obecnych na FB. Jest to dokładnie taki sam odsetek jak w przypadku udziału kobiet w całej populacji kandydatów ${ }^{6}$. Średnia wieku kandydatów mających swój fanpage to 40 lat - o trzy lata mniej niż średni wiek osoby kandydującej w okręgu 13. W pewnym stopniu jest to zgodne z ogólną prawidłowością, wskazującą, że osoby młodsze znacznie częściej korzystają z ICT, a zwłaszcza z serwisów społecznościowych. W przypadku badanej populacji istotność tej zależności nie została jednak potwierdzona $\mathrm{w}$ analizie statystycznej?.

Od samego posiadania strony na Facebooku istotniejsza jest oczywiście realizowana na niej aktywność. W analizowanym okresie na wszystkich fanpage'ach opublikowanych zostało 3228 wpisów. Oznacza to, że średnio każdy kandydat opublikował w czasie całej kampanii wyborczej 41 wpisów, czyli niewiele ponad jeden wpis dziennie $(1,08)$. Trudno tego rodzaju rezultat uznać za dowód na intensywne wykorzystywanie FB w komunikowaniu się z wyborcami. Istotą serwisów społecznościowych jest przecież szybkie reagowanie na wydarzenia $\mathrm{i}$ intensywna interakcja $\mathrm{z}$ użytkownikami. Kampania wyborcza jest niemal

${ }^{6}$ Brak wpływu płci jako zmiennej determinującej posiadanie fanpage’a na FB potwierdza analiza statystyczna. Wartość współczynnika $\phi$ wyniosła 0,00 .

7 Wskaźnik $\phi: 0,163$. 
nieskończonym ciągiem kolejnych zdarzeń, a więc statystyczna aktywność na poziomie jednego wpisu dziennie sugeruje, że Facebook nie był przez kandydatów traktowany jako stale wykorzystywany, podstawowy kanał komunikacji, a raczej jako narzędzie uzupełniające, używane od przypadku do przypadku.

Analiza korelacji podstawowych zmiennych demograficznych z liczbą materiałów publikowanych na FB nie wykazała istotnych zależności. Dotyczy to zarówno płci kandydatów ${ }^{8}$, ich wieku ${ }^{9}$, jak i miejsca zamieszkania ${ }^{10}$. Na poziomie opisowym znaczące były natomiast różnice między aktywnością kandydatów należących do konkretnych komitetów wyborczych. Z tego punktu widzenia liderami byli politycy PiS i Nowoczesnej (średnia liczba wpisów na jednego kandydata, odpowiednio: 50,1 i 49,7), a tuż za nimi plasowali się kandydaci z listy PO i komitetu „Szczęść Boże!” (średnia wpisów - 45). Reprezentanci wszystkich pozostałych komitetów wykazali się aktywnością mniejszą niż średnia dla całej próby ${ }^{11}$, a zdecydowanie najmniej intensywnie z Facebooka korzystali kandydaci Kongresu Nowej Prawicy (KNP), którzy średnio umieścili na każdym ze swych fanpage’y 15 wpisów w czasie całej kampanii ${ }^{12}$.

Dane te pokazują, że kandydaci poszczególnych ugrupowań funkcjonują w świecie ICT na bardzo różnym poziomie. Charakterystyczne jest w tym kontekście porównanie dwóch partii prawie tożsamych ideowo i odwołujących się do podobnych wyborców - KNP i KORWiN. Kandydaci z ramienia tej pierwszej nie tylko ponad trzykrotnie rzadziej posiadali stronę na Facebooku, ale jednocześnie ci - nieliczni - którzy się na to zdecydowali byli prawie trzykrotnie mniej aktywni na swych fanpage’ach niż przedstawiciele ugrupowania Janusza Korwin-Mikkego. Interpretacja tych różnic wymagałaby pogłębionych badań na większej próbie, ale już zaprezentowany obraz dowodzi, że termin „kandydat na Facebooku" nawet w przypadku tego samego okręgu wyborczego jest statystyczną abstrakcją, na którą składają się biegunowo różne style zachowania.

8 Wskaźnik $\phi: 0,178$.

${ }^{9}$ Wskaźnik tau-B: 0,174 .

10 Wskaźnik $\phi: 0,239$.

11 PSL - 40,5 wpisów, KORWiN - 38,3, Razem - 35,5, Kukiz'15 - 35,2, Zjednoczona Lewica - 28,6.

12 Warto jednak pamiętać, że tylko trzech kandydatów z listy KNP posiadało stronę na FB (wobec np. $17 \mathrm{w}$ przypadku PiS). Średnia odzwierciedla więc w tym przypadku raczej indywidualne zachowania niż prawidłowości związane ze specyfiką ugrupowania. 


\section{Tematyka wpisów}

Jak wspomniano wcześniej, tematyka wpisów ${ }^{13}$ została podzielona na pięć szczegółowych kategorii. Warto jednak dodać, że nie zawsze publikowany materiał miał charakter jednorodny i w związku z tym niemożliwe było zaklasyfikowanie go wyłącznie jako wpisu o charakterze informacyjnym czy promocyjnym. W tego rodzaju przypadkach post był przyporządkowywany do każdej z kategorii tematycznych, których elementy obejmował. W efekcie całkowita liczba wpisów analizowana z punktu widzenia ich tematyki jest większa niż podana wcześniej liczba wpisów, rozumiana jako ogólna miara aktywności kandydatów ${ }^{14}$. Podział opublikowanych materiałów ze względu na ich tematykę prezentuje tabela 2.

Tabela 2. Podział wpisów ze względu na tematykę

\begin{tabular}{|c|c|c|}
\hline Kategoria & Liczba & $\%$ \\
\hline Promocyjne & 922 & 23,1 \\
Mobilizacyjne & 332 & 8,3 \\
Informacyjne & 1780 & 44,6 \\
Społeczno-gospodarcze & 596 & 14,9 \\
Inne & 363 & 9,1 \\
Razem & 3993 & $\mathbf{1 0 0 , 0}$ \\
\hline
\end{tabular}

Źródło: Opracowanie własne.

Wśród wpisów zdecydowanie dominują te o charakterze informacyjnym, stanowiąc blisko połowę (44,6\%) aktywności kandydatów w czasie kampanii wyborczej. Jak wspomniano wcześniej, kategoria ta obejmowała kilka rodzajów materiałów. Najpopularniejszymi okazały się informacje o spotkaniach z wyborcami (ok. 34\% wszystkich postów informacyjnych) oraz informacje na temat postulatów programowych (21\%). Mniej liczne były wpisy o charakterze biograficznym, skierowane przeciw kontrkandydatom albo dotyczące procedury głosowania (po ok. 10\%).

Prawie co czwarty wpis $(23,1 \%)$ miał charakter promocyjny, a dominowały wśród nich zaproszenia - na debaty, konferencje czy do wysłuchania audycji radiowych lub telewizyjnych $\mathrm{z}$ udziałem kandydata (24,7\% wpisów promocyj-

13 Przez wpis należy rozumieć każdy typ materiału dostępny na analizowanej stronie (tekst, zdjęcie, film, odnośnik, udostępnienie innej strony na FB itd.).

14 Wartości te to, odpowiednio: 3228 i 3993. 
nych). Popularne były też „meldunki” - przeważnie zdjęcia - z przebiegu kampanii outdoor $(24,3 \%)$, rzadko natomiast kandydaci chwalili się rekomendacjami uzyskanymi od innych osób (12,6\%).

$\mathrm{Na}$ Facebooku znaczącą rolę odegrało też w czasie kampanii wyborczej komentowanie bieżących wydarzeń i odnoszenie się do problemów społecznych. $\mathrm{Na}$ obejmującą te kwestie kategorię materiały społeczno-gospodarcze przypadał prawie co siódmy wpis (14,9\%). Nad refleksją o charakterze programowym przeważały tu jednak doraźne problemy i konflikty polityczne $(25,1 \%$ wpisów społeczno-gospodarczych), komentowanie sukcesów sportowców, wydarzeń kulturalnych $(23,4 \%)$ czy problem uchodźców (19,9\%). Co ciekawe, mimo wyraźnie obecnego w kampanii tematu świadczeń społecznych (program 500+, bezpłatne leki dla osób starszych) szeroko rozumiane problemy seniorów i związane z wychowaniem dzieci były tematem tylko pojedynczych wpisów (odpowiednio: $1,2 \%$ i $0,5 \%)^{15}$. Pokazuje to wyraźnie, że serwisy społecznościowe są znacznie chętniej wykorzystywane przez kandydatów do zabierania głosu w kwestiach bieżących niż do stymulowania debaty na ważne, ale mniej „gorące” tematy społeczne czy ekonomiczne.

Najmniej popularne okazały się wpisy o charakterze mobilizacyjnym ${ }^{16}$, stanowiące zaledwie jedną dwunastą część (8,3\%) całej aktywności kandydatów. Wśród tego rodzaju materiałów zdecydowanie dominowały wezwania do udziału w wyborach, ale także prośby o poparcie w sondach i plebiscytach internetowych (66\% wszystkich postów mobilizacyjnych $)^{17}$. Warto jednak zwrócić uwagę, że w sumie wpisów zawierających apel: „Głosujcie!” opublikowano w całej kampanii 233, co oznacza, że statystyczny kandydat umieścił na swym fanpage’u średnio trzy tego typu wezwania w czasie całej kampanii. Jeśli pamiętać, że analizowany okres obejmował $38 \mathrm{dni}$, to oznacza, że wpis mobilizacyjny pojawiał się na statystycznej witrynie średnio raz na prawie dwa tygodnie. Dane te są jednoznaczne i dowodzą, że potencjał mobilizacji wyborczej istniejący w serwisach społecz-

15 Należy pamiętać, że wypowiedzi dotyczące ogólnych kwestii społecznych mogły znaleźć się także wśród wpisów poświęconych programowi kandydatów, które były kategoryzowane w ramach postów informacyjnych.

${ }^{16} \mathrm{~W}$ analizie pomijamy kategorię „Inne”, na którą przypadało 9,1\% wpisów. Obejmowała ona mniej typowe aktywności kandydatów, takie jak podziękowania, życzenia okolicznościowe, a nawet zdjęcia faktur ilustrujące wydatki na kampanię.

17 Dwie pozostałe istotne, ale zdecydowanie rzadziej wykorzystywane kategorie wpisów mobilizacyjnych, to prośby o finansowe wsparcie kampanii (17\%) i apele o udostępnienie opublikowanych na stronie materiałów $(14,7 \%)$. 
nościowych w polskich realiach politycznych ciągle czeka na wykorzystanie. $\mathrm{Na}$ razie tego typu aktywność pozostaje marginalnym aspektem komunikowania politycznego w sieci.

\section{PODSUMOWANIE}

Wyniki badań przedstawione w tym tekście potwierdzają, że serwisy społecznościowe odgrywają coraz istotniejszą rolę w polskich kampaniach wyborczych. Ciągle jednak narzędzia sieciowe stanowią wyłącznie uzupełnienie dobrze znanych, opartych na tradycyjnych kanałach komunikowania $z$ wyborcami. Wydaje się, że zmiana istniejących wzorców zajmie więcej czasu niż można się było spodziewać jeszcze niedawno. Pośrednio dowodzi tego fakt, że nie potwierdziła się pierwsza $z$ testowanych hipotez. Nie istnieje statystyczny związek między młodym wiekiem kandydatów a gotowością do wykorzystywania Facebooka w kampanii wyborczej (zarówno w sensie posiadania strony, jaki i intensywnością korzystania z niej). Nieunikniona dominacja życia politycznego przez pokolenie od kolebki korzystające z ICT niekoniecznie zaowocuje więc szybkim przeniesieniem punktu ciężkości komunikowania wyborczego na narzędzia sieciowe, w tym serwisy społecznościowe. Te ostatnie są zresztą ciągle wykorzystywane w sposób typowy dla wstępnego etapu rozwoju Internetu. Wskazuje na to potwierdzenie się drugiej ze sformułowanych w badaniach hipotez. Zgodnie z nią strony na Facebooku są w kontekście wyborczym traktowane przez polityków głównie jako źródło informacji dla potencjalnych wyborców, a w bardzo małym stopniu jako instrument mobilizacji swych zwolenników. Dla pesymisty oznacza to marnowanie możliwości stwarzanych przez ICT, dla optymisty olbrzymią szansę na rozwój kampanii sieciowej w przyszłości. Niezależnie od tego, która z tych perspektyw jest bardziej adekwatna, każdy badacz musi uznać za oczywiste, że wykorzystanie serwisów społecznościowych w kampaniach wyborczych na długo pozostanie przedmiotem wnikliwej analizy.

\section{Bibliografia:}

Bimber, B. (2014). Digital Media in the Obama Campaigns of 2008 and 2012: Adaptation to the Personalized Political Communication Environment. Journal of Information Technology \& Politics, 11 (2), s. 130-150. 
Bodys, M. (2015). Wykorzystanie mediów społecznościowych przez polskie parlamentarne partie polityczne poza okresem kampanii wyborczych. Wrocławskie Studia Politologiczne, 18, s. 109-133.

Camaj, L., Santana, A. (2015). Political Deliberation on Facebook during Electoral Campaigns: Exploring the Relevance of Moderator's Technical Role and Political Ideology. Journal of Information Technology \& Politics, 12 (4), s. 325-341.

Choroś, B., Skrabacz, E. (2014). Komunikacja polityczna w Internecie na szczeblu lokalnym. Rekonesans badawczy. Polityka i Społeczeństwo, 3 (12), s. 141-155.

Dolezal, M. (2015). Online Campaigning by Australian Political Candidates: Determinants of using personal Websites, Facebook and Twitter. Policy \& Internet, 7 (1), s. $103-119$.

Fras, J. (2012). Profile partii politycznych na Facebooku w kampanii wyborczej 2011 roku. Roczniki Nauk Społecznych, 4 (40), nr 3, s. 55-73.

Gerodimos, R., Justinussen, J. (2015). Obama’s 2012 Facebook Campaign; Political Communication in the Age of the Like. Journal of Information Technology \& Politics, 12 (2), s. 113-132.

Hansen, K., Kosiara-Pedersen, K. (2014). Cyber-Campaigning in Denmark: Application and Effects of Candidate Campaigning. Journal of Information Technology \& Politics, 11 (2), s. 206-219.

Hendricks, J., Denton, R. (red.). (2010) Communicator-in-Chief: How Barrack Obama Used New Media Technology to win the White House. Lanham: Lexington Books.

Karlsen, R. (2011). A Platform for Individualized Campaigning? Social Media and Parliamentary Candidates in the 2009 Norwegian Election Campaign. Policy \& Internet, 3 (4), s. 1-25.

Kowalik, K. (2013). Kampania wyborcza świętokrzyskich kandydatek i kandydatów do parlamentu $2011 \mathrm{w}$ portalu społecznościowym Facebook.com. Studia Medioznawcze, 4 (55), s. 63-75.

Olczyk, T. (2015). Facebook w kampanii prezydenckiej w 2015 roku - analiza zawartości profili Andrzeja Dudy i Bronisława Komorowskiego. E-Politikon, XVI, s. 57-85.

Piechota, G. (2012). Wykorzystanie serwisu społecznościowego Fcebook w komunikacji politycznej miast Metropolii Silesia i ich prezydentów. Studia Medioznawcze, 1 (48), s. $75-87$.

Porębski, L., Karasek-Kędzior, K. (2014). Serwisy społecznościowe jako narzędzie dialogu z wyborcami. Profile polskich partii politycznych na Facebooku. Studia Humanistyczne AGH, 13 (1), s. 59-75.

Porębski, L., Karasek-Kędzior, K. (2015). Facebook a polityka. Wykorzystanie serwisów społecznościowych przez polskie partie polityczne. Athenaeum. Polskie Studia Politologiczne, 45, s. 176-190.

Robertson, S., Vatrapu, R., Median, R. (2010). Off the wall political discourse: Facebook use in the 2008 U.S. presidential election. Information Polity, 15 (1-2), s. 11-31.

Towner, T. (2012). Campaigns and Elections in a Web 2.0 World: Uses, Effects and Implications for Democracy. W: Ch. Reddick, S. Aikins (red.). Web 2.0 Technologies and Democratic Governance, s. 185-199. New York: Springer. 
Shaw, C. (2013). The Campaign Manager: Running and Winning Local Elections. Boulder: Westview Press.

Štetka, V., Mazák, J. (2014). Whither Slactivism? Political Engagement and Social Media Use in the 2013 Czech Parliamentary Elections. Journal of Psychosocial Research on Cyberspace, 8 (3). Pobrane z: http://www.cyberpsychology.eu/view.php?cisloclanku=2014100 102 .

Stopczyński, B. (2015). Wykorzystanie portali społecznościowych w kampanii wyborczej - analiza działań kandydatów ubiegających się o urząd prezydenta miasta Łodzi. Przedsiębiorczość i Zarządzanie, XVI, 12 (I), s. 205-219.

Vaccari, C., Nielsen, R. (2013). What Drives Politicians' Online Popularity: An Analysis of the 2010 US Midterm Elections. Journal of Information Technology \& Politics, 10 (2), s. 208-222.

Williams, Ch., Gulati, G. (2007). Social Networks in Political Campaigns: Facebook and the 2006 Midterm Elections. Paper presented at the 2007 Annual Meeting of the American Political Science Association Chicago, Illinois, August 30 - September 2, 2007. Pobrane z: http://blogs.bentley.edu/politechmedia/wp-content/uploads/2007/09/apsa-2007-facebook1.pdf.

Williams, Ch., Gulati, G. (2013). Social Networks in Political Campaigns: Facebook and the Congressional Elections of 2006 and 2008. New Media \& Society, 15 (1), s. $52-71$.

Williamson, A. (2010). 2010: The Internet Elections That Wasn't. Political Insight, 1 (2), s. $58-60$. 